\title{
Determining the Regime Shift of the Baltic Sea Ice Seasons during 1982-2016
}

\section{Određivanje režima promjene ledenih sezona Baltičkoga mora od godine 1982. do 2016.}

\author{
Jevgeni Rjazin \\ EstMare OU \\ Tallinn, Estonia \\ e-mail: jekki.augustiinus@yahoo.com $\quad$ e-mail: Ove.PARN@ext.ec.europa.eu \\ Ove Parn \\ EstMare OU \\ Tallinn, Estonia
}

\author{
DOI 10.17818/NM/2020/1.8 \\ UDK 629.541.2:656.66 \\ Preliminary communication / Prethodno priopćenje \\ Paper accepted / Rukopis primljen: 7. 1. 2020.
}

Summary

The distributions of ice season characteristics in the Baltic Sea during 1982-2016 were studied. A shift in the ice season regime was observed in 2006-2007. Ice season characteristics before and after the shift were determined in the northern and southern regions of the Baltic Sea, and the contributions of these areas to the shift regime were evaluated. To study changes in ice conditions, satellite data on the daily ice concentration over the Baltic Sea provided by the Copernicus Marine Environment Monitoring Service were used. The ice cover extent and number of ice days were calculated. The maximal ice extent event of the ice season shifted from the beginning of March to the end of January in 2007. The average ice concentration over the Baltic Sea was $18 \%$ and $10 \%$ before and after the shift, respectively. On average, 32 and 19 ice days occurred before and after the shift, respectively. The average ice concentration in the northern Baltic was $54 \%$ before and $34 \%$ after the shift, and the concentration in the southern Baltic was $8 \%$ before and $7 \%$ after the shift. The determined shift of the ice season characteristics indicated that extensive ice cover does not last long during the after-shift seasons.

\section{Sažetak}

Proučavale su se karakteristike rasporeda ledene sezone na Baltičkome moru od godine 1982. do 2016. Promjena u režimu ledene sezone uočena je 2006. i 2007. godine. Karakteristike ledene sezone prije izmjene i nakon nje određene su u sjevernim $i$ južnim regijama Baltičkoga mora te su evaluirani doprinosi ovih prostora na promjenu režima. Da bismo proučili promjene u uvjetima leda, satelitski podatci o koncentraciji leda nad Batičkim morem, korišteni su podatci koje je priskrbila Copernicus nadzorna služba za pomorski okoliš. Izračunata je debljina sniježnoga pokrivača i broj ledenih dana. Maksimalan razmjer ledenoga događaja, ledene sezone, pomakao se od početka ožujka do kraja siječnja 2007. Prosječna koncentracija nad Baltičkim morem bila je 18 $\%$, a $10 \%$ prije promjene i nakon nje, redoslijedom navođenja. Prosječno 32 i 19 ledenih dana dogodilo se prije promjene i nakon nje prema redoslijedu navođenja. Prosječna koncentracija leda na sjevernome Baltiku bila je $8 \%$ prije, a $7 \%$ nakon promjene, a koncentracija na južnome Baltiku bila je $8 \%$ prije, a $7 \%$ nakon promjene. Određena promjena karakteristika ledene sezone pokazuje da sniježni pokrivač ne traje dugo tijekom sezona nakon promjene.

\section{KEY WORDS \\ Baltic Sea climate \\ ice season \\ ice concentration \\ climatic regime \\ regime shift \\ ice days}

\author{
KLJUČNE RIJEČI \\ klima Baltičkoga mora \\ ledena sezona \\ koncentracija leda \\ klimatski režim \\ promjena režima \\ ledeni dani
}

\section{INTRODUCTION / Uvod}

The Baltic Sea is a narrow body of water extending approximately 1600 km meridionally (Fig. 1). Thus, climatic conditions differ considerably in its northern and southern regions. The sea is an inseparable part of human activities in the region, and ice phenomena adversely affect winter navigation, fishery and recreation, sea-atmosphere energy exchange, and the marine ecosystem.

Variability and changes in ice cover have been spotted, studied, and recognised as an essential phenomena for centuries. Relevant data are available in harbour logbooks of the 14 th century $[1,2]$.
Ice extent and ice cover duration are the properties generally used for characterising ice seasons. On average, a maximal ice extent (Emax) of approximately $165,000 \mathrm{~km}^{2}$ occurs on the Baltic Sea in March (covering $40 \%$ of the total area of the Baltic Sea) [3]. Emax in 1956-2005 was 405,000 km², which occurred in the winter of 1986/87 [4]; however, in the recent period 20072016, Emax was $309,000 \mathrm{~km}^{2}$, which occurred in the winter of 2010/11 [5].

The Emax of the season varies from year to year because of large-scale variations in atmospheric circulation characterised by the North Atlantic Oscillation (NAO) index, and it exhibits a 
significant decreasing trend [3,6]. The relationship between the NAO index and Emax has changed over time [7].

All pertinent studies have reported a significant decreasing trend in Emax. The trend for the past 100 years is $-3400 \mathrm{~km}^{2}$ per 10 years [3].

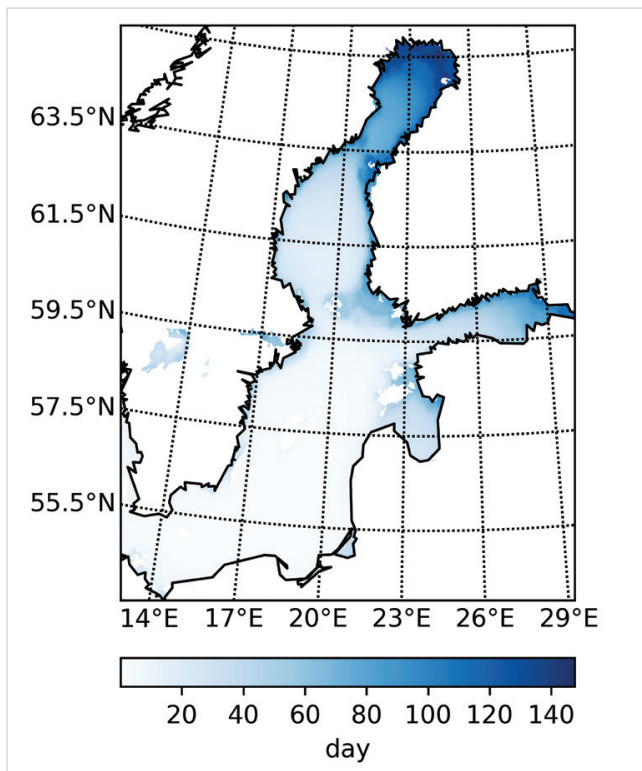

Figure 1 The numbers of ice days in the Baltic Sea in 1982-2016. Slika 1. Broj danâ leda na Baltičkome moru od 1982. do 2016. godine

The duration of ice season is 130-200 days in the Bothnian Bay, 80-100 days in the Gulf of Finland, and 0-60 days in the southern Baltic Sea [8]. Jevrejeva et al. [9] reported a decreased ice season length of 14-44 days over the past 100 years, which was primarily because of relatively early ice break-up.

In recent winters, ice conditions in the Baltic Sea have shown strong interannual variability [3]. One method to study climate change is to describe it as a smooth changing process. For example, Jaagus et al. [10] studied temperature series of the eastern Baltic region and identified increasing trends in the maximal and minimal temperatures. According to Kahru et al. [11], the duration of the period with a mean sea surface temperature of at least $16^{\circ} \mathrm{C}$ has increased from approximately 40 days in 1982 to approximately 72 days in 2014 (i.e. by 32 days).

However, specifying comparatively persistent states of climatic characteristics and shifts between such states is possible. This approach is expressed through climate regimes and their shifts, which are crucial concepts that facilitate the understanding of climatic variability and its effects on the ecosystem. These concepts consider a climatic or ecological system as a sequence of its multiple persistent states and shifts between these states. Regimes and their shifts have been considered in the study of decadal climate variability in the North Pacific [12]. Various climatic features of the Baltic Sea, including temperatures and ice phenomena and ecosystem characteristics, have been studied with respect to different quasi-persistent states [13-15]. According to Kahru et al. [11], the transparency of water has decreased since 2007 in the central Baltic Sea.

The authors of the present paper have previously studied the properties of ice seasons during 1982-2016. Ice cover extent and duration are discussed by Pärn et al. [16]. The behaviour of ice cover changed sharply near 2006-2007. The initial part of 1982-2016 exhibited a greater number of ice seasons with a higher ice extent and longer duration than the latter part. The winters in the initial parts had relatively long-lasting ice cover. At the end of the studied period, maximal ice cover stayed only for a short time [17].

In the present study, the basic properties of the ice season, extent and duration of ice cover, and some related climatic properties during 1982-2016 were investigated. In this paper, the relationship between the two basic properties of ice cover is considered, and a pattern discovered in their behaviour is described.

The following ice season and climatic characteristics were studied: ice concentration and ice distribution over the Baltic Sea; the number of ice days and weighted ice days; the date of the maximal ice extent event; peak duration value (i.e. the number of ice days with the ice extent of at least $80 \%$ of the season maximum), which is used to expresses the relational duration of extensive ice cover; characteristic difference between the relative values of ice extent sum (IES) and the Emax of the season ( $\Delta \mathrm{ch}$, which indicates how stable or momentary the ice cover is in a given ice season, [considered in chapter 2.2]); the sum of negative degree days; average air temperature; and skewness (asymmetry coefficient) of air temperature distribution. The values of these characteristics were processed according to the Rodionov algorithm to determine their changes.

A regime shift in the ice season was determined between 2006 and 2007. The distributions of the aforementioned ice season characteristics before and after the shift were studied. Whether the shift in ice conditions was observed over the entire Baltic Sea or appeared differently in the northern and southern sea areas was assessed. The contributions of the northern and southern regions of the Baltic Sea to the shift in trends of the ice season characteristics were determined.

The paper is organized as follows. Section 2 contains a short description of data sources used for analyses, formulas and Rodionov method. Results are performed in section 3. Analyzed of ice season characteristics in the Baltic Sea. The brief discussion and conclusion of the study is presented in section 4 .

\section{MATERIALS AND METHODS / Materijali i metode} 2.1 The basic data / Osnovni podatci

The daily ice concentrations over the Baltic Sea were provided by the Copernicus Marine Environment Monitoring Service (http:// marine.copernicus.eu/). The ice concentration data from the Swedish Ice Service and radiometric satellite observations were obtained using the sensors AVHRR, ATSR-1, ATSR-2, and AATSR.

These data were used to calculate the ice cover characteristics of the Baltic Sea for the ice seasons in 1982-2016. These characteristics were determined for each season.

Ice extent was defined as the area of the sea with an ice concentration of at least $10 \%$. Areas with ice concentrations of less than $10 \%$ were considered ice-free (open water) areas. All grid cells that exhibited the presence of ice were summed to obtain the daily ice extent. Ice was considered to be present in the cell if the ice concentration was $\geq 10 \%$. Emax was identified among the daily ice extents for each season. The season Emax calculated using these data was approximately $20 \%$ higher than the values recorded by the Finnish Meteorological Institute 
(http://en.ilmatieteenlaitos.fi/baltic-sea-ice-winters).The seasons were evaluated on the basis of their relative Emax, sum of relative ice extent, and number of weighted ice days.

Considering the zonal variability of ice and other climatic conditions, the Baltic Sea was divided zonally into two parts in the present study. The northern region comprised the Bothnian Bay, Bothnian Sea, and Gulf of Finland, as specified in a study by Ruskule [19], and the remainder constituted the southern region (Fig. 1).

\subsection{IES and characteristic differences in the season / IES i karakteristične sezonalne razlike}

The IES describes the ice cover extent from the appearance of ice to its break-up. It was calculated using the following formula:

$$
I E S=\sum_{t_{0}}^{t_{n}} A_{t},\left(\mathrm{~km}^{2}\right)
$$

Where $A_{t}\left(\mathrm{~km}^{2}\right)$ is the ice cover extent on day $t, t_{0}$ is the ice appearance date, and $t_{n}$ is the last day of the ice cover. The ice extent of the day was calculated using data of the ice concentration obtained using remote sensing methods.

The ratios of Emax and IES in a particular season to their maximal values within the studied period were calculated $E_{\max _{r}}$ andIES$S_{r}$. The reference season with the maximum was the winter of $1986 / 87$, when $97 \%$ of the entire Baltic Sea area was covered by ice. The characteristic difference of the ice seasons was calculated using the following formula:

$$
\Delta c h=I E S_{r}-\operatorname{Emax}_{r},(\%)
$$

both for the northern and southern Baltic regions.

\subsection{Rodionov method / Rodionova metoda}

A regime shift detection method was used to identify regime shifts in time series. We used the Rodionov algorithm $[12,18]$ and the Rodionov script, which was downloaded from the Bering Sea Climate website http://www.beringclimate.noaa. gov/regimes/.

We studied changes in ice conditions in the Baltic Sea. Therefore, we used the following set of input parameters: I = 10 years, $p=0.1$, and HWP $=1$. HWP determines the weight of outliers in the calculation of mean values before and after the shift. The output of the test is a year when a regime shift occurs (i.e. the first year of the new level).

\section{RESULTS / Rezultati}

\subsection{Regime shift in the Baltic Sea / Promjena režima na Baltičkome moru}

A regime shift in the ice season characteristics was determined in 2006-2007.

The ice season characteristic difference $\Delta c h$ mainly had negative values for 1982-2006, but it was positive for 20072016, except for 2008 (Fig. 2). Negative values of $\Delta c h$ indicated the seasons (winters) in which ice cover lasted longer, whereas positive values indicated the seasons (winters) in which the ice cover was extensive for some time but did not last long [20]. Therefore, the difference $\Delta c h$ of the season shifted from the negative to positive. The negative value indicated that nearEmax lasted for a longer time, whereas positive value indicated that the peak values occurred only for a short period.

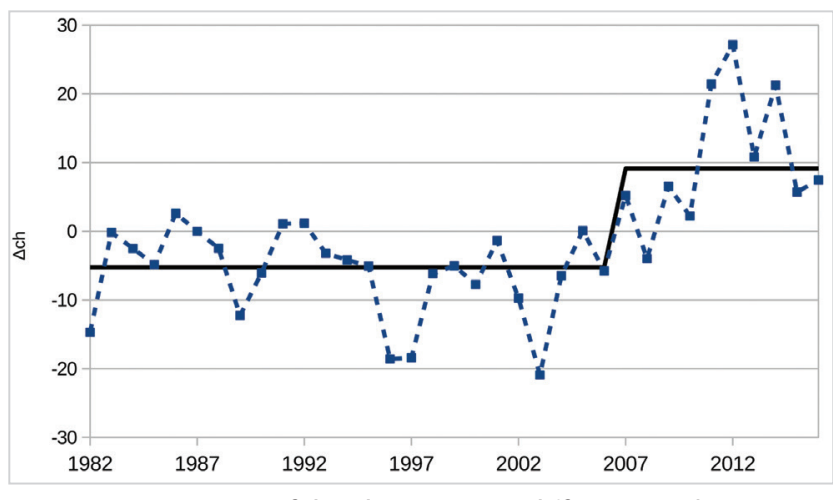

Figure 2 Time series of the characteristic difference $\Delta c h$ in winter during 1982 - 2016, its regime shifted since 2007 (black line)

Slika 2. Vremenska serija karakteristične razlike $\Delta$ ch zimi za vrijeme razdoblja od 1982. do 2016. godine.

The peak ice cover duration value (the number of days with an ice extent of at least $80 \%$ of the season's maximum) indicated the length of the peak time in comparison with the total duration of the particular ice season. The average peak duration was 30.5 days for 1982-2006 but reduced to 14.9 days from 2007 onwards (Fig. 3). This change revealed that extensive ice cover does not last long in the after-shift seasons.

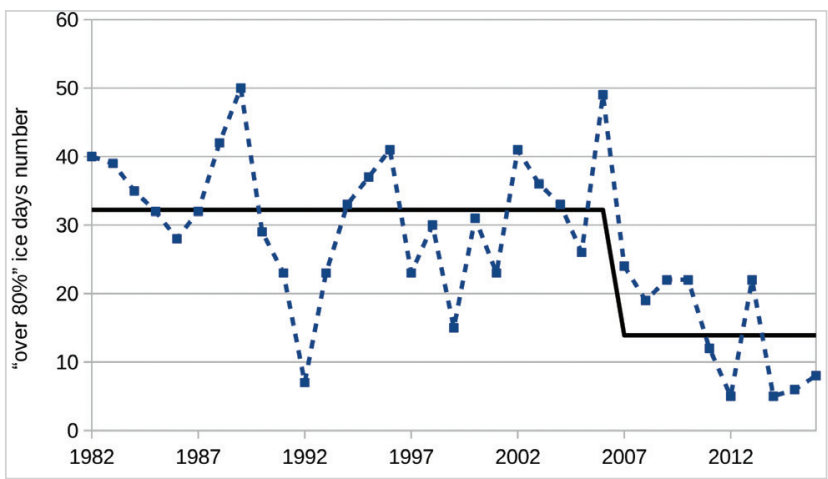

Figure 3 Time series of the "over $80 \%$ " ice days number in winter during 1982 - 2016, its regime shifted since 2007 (black line).

Slika 3. Vremenska serija "preko 80\%" ledenih dana zimi za vrijeme razdoblja od 1982. do 2016. godine, čiji se režim promijenio od 2007. godine (crna linija)

The skewness of air temperature distribution indicated the degree of variation in air temperature values throughout a given season. We studied the skewness values both in the northern and southern Baltic regions. The areas corresponding to $65^{\circ} \mathrm{N}$ $25^{\circ} \mathrm{E}$ and $55^{\circ} \mathrm{N} 20^{\circ} \mathrm{E}$ were selected to represent the northern and southern Baltic regions, respectively.

In the southern Baltic region, the average skewness of air temperature distribution shifted from 0.39 to 0.8 in 2006 (Fig. 4). This change indicated that the air temperature distribution in the southern region varied considerably more in the final part of the reviewed period. No such shift was observed in the northern region. 


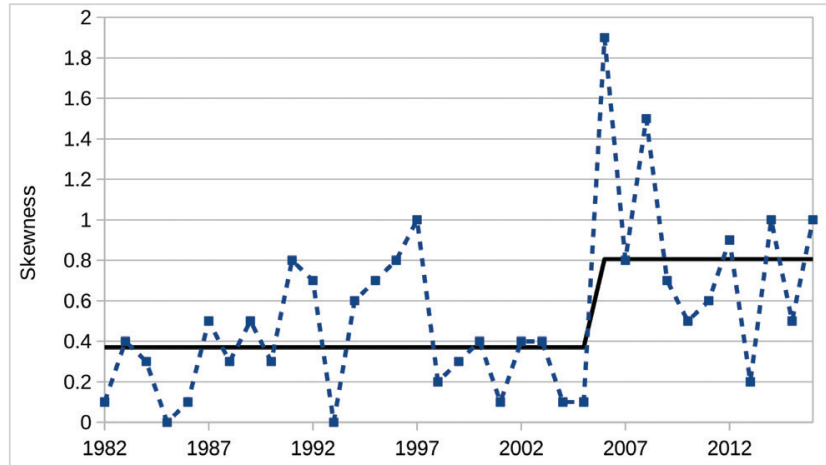

Figure 4 Time series of the daily air temperature distribution skewness in winter during 1982 - 2016, its regime shifted since 2007 (black line). Daily air temperature (on $65^{\circ} \mathrm{N} 25^{\circ} \mathrm{E}$ as the North and $55^{\circ} \mathrm{N} 20^{\circ} \mathrm{E}$ as the South) originate from the NCEP/ NCAR reanalysis data for 1981-2016.

Slika 4. Vremenska serija asimetrične distribucije dnevnih temeperatura zraka zimi za vrijeme razdoblja od 1982. do 2016. godine, čiji se režim promijenio od 2007. (crna linija). Dnevne temperature zraka (na $65^{\circ} \mathrm{N} 25^{\circ} \mathrm{E}$ kao sjever i $55^{\circ} \mathrm{N} 20^{\circ} \mathrm{E}$ kao jug) iz izvora NCEP/NCAR podataka ponovne analize za razdoblje od 1981. godine do 2016

\subsection{Climatic characteristics before and after the shift / Klimatske karakteristike prije promjene i nakon nje}

The daily ice extent exhibited considerable fluctuations in the data series. Moving averages of ice extents over 5 days were calculated to smoothen these fluctuations. Spectra of the ice extent growth rates were generated, and the spectral period was 5 days.

The surveyed period was divided to three subperiods: 1982-1994, 1995-2007, and 2008-2017 (Fig. 5). The maximal ice extent event of ice season shifted from 5 March to 25 January since 2008. In the winters after the shift, ice cover thrived as previously but began to recede earlier. The ice extent grew up to the end of January with same rate before and after the shift, reaching approximately $122,000 \mathrm{~km} 2$ on 25 January (Fig. 5). The ice receded from this date after the shift; however, before the shift, the ice extent continued to grow after 25 January. A regime shift was observed in the air temperatures of March; however, it did not explain the decrease in ice extent 1 month earlier.

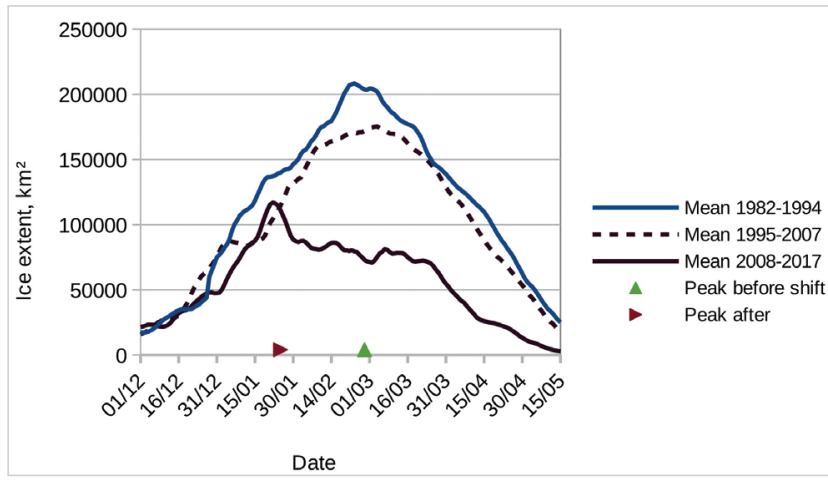

Figure 5 The mean daily ice extents before and after the shift. The red line denotes the mean before the shift and the blue after the shift

Slika 5. Srednji razmjer leda prije i poslije promjene. Crvena linija označava sredinu prije promjene, a plava nakon promjene
We examined the cause of change in the wind direction distribution. Wind deforms sea ice and affects sea ice distribution. Furthermore, wind causes waves, which can break ice and resist the formation of new ice.

The distribution of wind direction was identified with speed at least $4 \mathrm{~m} / \mathrm{s}$ during the scope 20 January to 4 March.

The wind directions were grouped clockwise into four quadrants. The wind blowing from $\mathrm{S}$ to $\mathrm{N}$ was considered $0^{\circ}$. The frequency of winds in the scope $1^{\circ}$ to $90^{\circ}$ increased by 34\% during 1982-2017 (Fig. 6). These winds blowing from the open water area towards the ice-covered areas deform the ice and shrink the ice-covered area. The frequency of winds in the scopes $91^{\circ}$ to $180^{\circ}$ and $181^{\circ}$ to $270^{\circ}$ decreased by approximately $40 \%$. These winds blew from the ice-covered areas towards the open water area and split sea ice, resulting in the extension of the ice-covered area. Consequently, the increase and decrease in the frequencies of winds in the scopes $1^{\circ}$ to $90^{\circ}$ and $91^{\circ}$ to $270^{\circ}$ favoured the shift towards a decrease in ice extent between 20 January and 4 March.

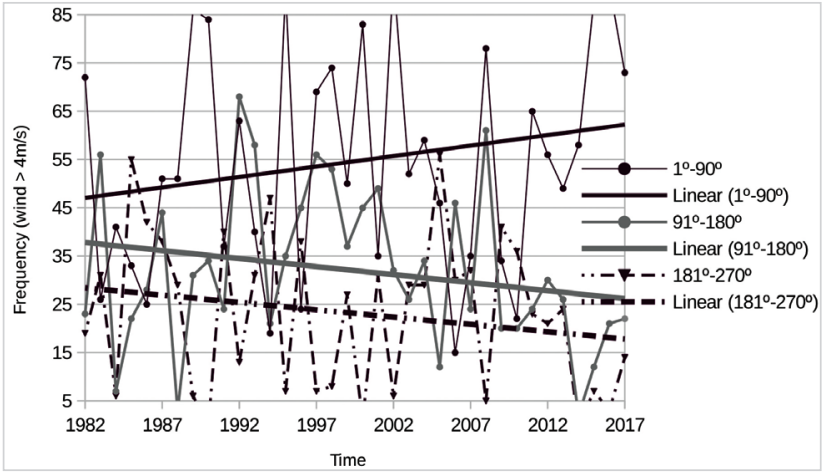

Figure 6 The distribution of wind direction with speed at least $4 \mathrm{~m} / \mathrm{s}$ within 20th Jan - 4th Mar.

Slika 6. Raspodjela smjera vjetra brzine najmanje $4 \mathrm{~m} / \mathrm{s}$ u razdoblju od 20. siječnja do 4. ožujka.

\subsection{Ice concentration and number of ice days / Koncentracija leda i broj ledenih dana}

The average ice concentrations over the Baltic Sea were compared for the periods before and after the shift. The maximal ice concentration over the Baltic Sea before the shift was $77 \%$ in the winter of $1986 / 87$, and the average value was $18 \%$. In the after-shift period, these values were $64 \%$ and $10 \%$, respectively.

The ice concentrations of the grid cells were averaged over the periods before and after the shift. The after-shift average values were subtracted from the respective before-shift values. The ice concentration had significantly decreased in a few areas. The entire Bothnian Bay exhibited the greatest decrease of 12\%$50 \%$. At the Finnish Coast, against Åland, the ice concentration decreased by $25 \%-35 \%$. The ice concentration decreased by $20 \%-50 \%$ near the northern shore of the Gulf of Finland and in its eastern part. However, the average ice concentration increased by $10 \%$ after the shift in Klaipeda Bay.

The average number of ice days on the Baltic Sea was calculated for the periods before and after the shift and was found to be 32 and 19 days, respectively. The spatial distribution of the number of ice days was determined. The number of ice 
days decreased by at least $50 \%$ in most parts of the icy area (Fig. 7). The data showed that the number of ice days increased by 10 days after the shift in the Southern Gdansk Bay and Klaipeda Bay. These findings were not emphasized because they are specific to these areas (enclosed and shallow). Satellite image processing algorithms are not reliable for such areas.

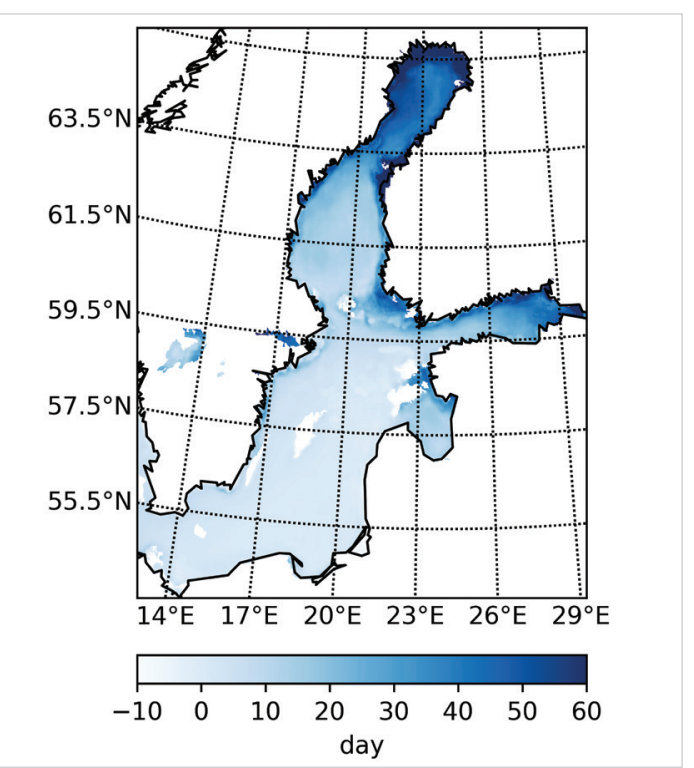

Figure 7 The difference between the mean numbers of ice days for the periods before and after the shift

Slika 7. Razlika između srednjega broja danâ leda za razdoblja prije i poslije promjene.

\subsection{Average air temperatures and sums of degree days / Prosječne temperature zraka i zbroj dana pozitivnih temperatura}

The monthly average air temperature, sum of negative degree days, and the sum of positive degree days (in March) vary between the periods before and after the shift.

Table 1 The monthly average air temperature values $\left({ }^{\circ} \mathrm{C}\right)$ before and after the shift. $\mathrm{N}$ stands for the northern and $\mathrm{S}$ for the southern part of the Baltic Sea. The data for the locations $65^{\circ} \mathrm{N}$ $25^{\circ} \mathrm{E}(\mathrm{N})$ and $55^{\circ} \mathrm{N} 20^{\circ} \mathrm{E}(\mathrm{S})$ for 1981-2016 from the NCEP/NCAR reanalysis data (http://dss.ucar.edu/). $\Delta$ stands for the difference.

Tablica 1. Mjesečni prosjek vrijednosti temperature zraka $\left({ }^{\circ} \mathrm{C}\right)$ prije i poslije promjene. N predstavlja sjever, a S jug Baltičkoga mora. Podatci su za lokacije $65^{\circ} \mathrm{N} 25^{\circ} \mathrm{E}(\mathrm{N}) \mathrm{i} 55^{\circ} \mathrm{N} 20^{\circ} \mathrm{E}(\mathrm{S})$ za godine od 1981. do 2016. od NCEP/NCAR baze ponovne analize podataka (http://dss.ucar.edu/). $\Delta$ predstavlja razliku

\begin{tabular}{|l|l|l|l|l|l|}
\hline & Dec & Jan & Feb & Mar & Apr \\
\hline before shift, N & -8.1 & -9.6 & -8.8 & -5.2 & -0.4 \\
\hline after shift, N & -5.3 & -9.6 & -8.5 & -3.9 & 1.2 \\
\hline$\Delta \mathrm{T}$ & +2.8 & 0 & +0.3 & +1.3 & +1.6 \\
\hline & & & & & \\
\hline before shift, S & 0.3 & -0.8 & -0.5 & 1.2 & 5.9 \\
\hline after shift, S & 1.3 & -1.2 & -0.8 & 2.6 & 7.4 \\
\hline$\Delta \mathrm{T}$ & +1.0 & -0.4 & -0.3 & +1.4 & +1.5 \\
\hline
\end{tabular}

As seen from Table 1, in the northern region, the monthly average air temperature values remained unchanged over the shift for January and February. The values indicated warmer air in December, March, and April after the shift. In the southern region, the values were almost the same in January and February but showed warming in December, March, and April after the shift. The monthly average air temperature increased in the southern region after the shift.

The sums of negative degree days $\left({ }^{\circ} \mathrm{C}\right.$.day) in the periods before and after the shift were similar during January, and most of February (Table 2). A difference occurred from the end of February. The northern region had an increase of $13 \%$ and the southern region had an decrease of $-20 \%$ in negative degree days after the shift at the end of ice season.

The southern Baltic region had a greater number of days with positive air temperature values after the shift than before it. However, the sum of negative degree days indicated a greater number of days with negative air temperature values after the shift than before it (Table 2). There were more days when the temperature is $+5^{\circ} \mathrm{C}$ degrees and more days when the temperature is below $-8^{\circ} \mathrm{C}$ degrees. The days with temperatures around $0^{\circ} \mathrm{C}$ had less.

Table 2 The sum of negative degree days $\left({ }^{\circ} \mathrm{C} \cdot\right.$ day) Tablica 2. Zbroj dana negativne temperature ( ${ }^{\circ} \mathrm{C}$ dan)

\begin{tabular}{|l|l|l|l|l|l|}
\hline & Dec & Jan & Feb & Mar & Apr \\
\hline & & & & & \\
\hline before sihft, N & -288 & -334 & -292 & -196 & -97 \\
\hline after shift, N & -234 & -325 & -287 & -180 & -51 \\
\hline$\Delta$ & 54 & 9 & 5 & 16 & 46 \\
\hline & & & & & \\
\hline before shift, S & -94 & -134 & -108 & -60 & -9 \\
\hline after shift, S & -114 & -142 & -129 & -78 & -4 \\
\hline$\Delta$ & -20 & -8 & -21 & -18 & 5 \\
\hline
\end{tabular}

The frequency distribution of air temperature values was calculated. All the low-degree extremes were recorded in the before-shift period in the northern and southern regions. High temperature values were more frequent during the after-shift period. The occurrence frequency analysis of air temperature values revealed that the days with air temperature over $+3^{\circ} \mathrm{C}$ were more frequent after the shift. The period after the shift showed a greater number of negative air temperature degree days as well as positive degree days (Fig. 8). About two times frequently appeared the temperature between $-15^{\circ} \mathrm{C} . . .-10^{\circ} \mathrm{C}$ and $+4^{\circ} \mathrm{C} . . .+6^{\circ} \mathrm{C}$, after the shift in south. The changes in the values of the studied climatic characteristics indicated that the air temperature was considerably more variable after the shift. Thus, the ice cover was less stable after the shift. 


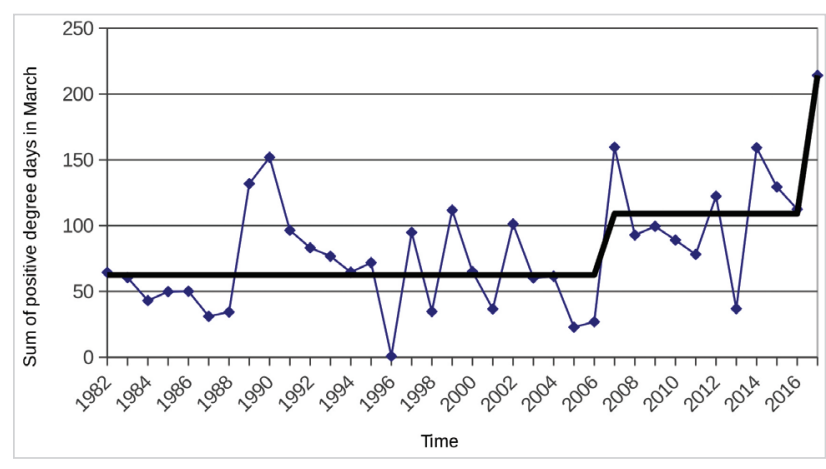

Figure 8 The sum of positive degree days in winter during 1982 - 2016, its regime shifted since 2007 (black line). Daily air temperature (on $57.5^{\circ} \mathrm{N} 20^{\circ}$ ) originate from the NCEP/NCAR reanalysis data for 1981-2016.

Slika 8. Zbroj dana pozitivnih stupnjeva temperature zimi za vrijeme razdoblja od 1982. do 2016. godine, čiji se režim promijenio od 2007. godine (crna linija). Dnevne temperature zraka $\left(57.5^{\circ} \mathrm{N}\right.$ $20^{\circ}$ ) dobivene iz podataka ponovne analize NCEP/NCAR za razdoblje od 1981. do 2016. godine.

\subsection{Regime shift in the northern and southern Baltic/ Promjena režima na sjevernome i južnome Baltiku}

We compared the average ice concentrations before and after the shift in the northern and southern regions of the Baltic defined for the present study. The seasonal ice concentrations were averaged over the respective periods in both parts. The ice concentration changed drastically in the northern Baltic region ( $54 \%$ before and $34 \%$ after the shift), but it remained mainly the same ( $8 \%$ before and $7 \%$ after the shift) in the southern Baltic region.

\section{DISCUSSION AND CONCLUSION / Rasprava $i$ zaključak}

The behaviour of the ice cover based on the main ice season characteristics during 1982-2016 was studied. The life cycle of ice cover changed in these years; consequently, we cannot regard its properties as resulting from a smooth sequence in the winters during that period.

The life of ice cover during the period studied is to be considered a sequence of two quasi-persistent states. The period before the shift in ice season regime in 2006-2007 was mostly characterised by winters with relatively lasting extensive ice cover. For example, the ice cover with an extent of at least $80 \%$ of the season maximum stayed, on average, for 30 days before the shift and for 15 days after it. The seasons with volatile ice cover started to dominate from 2007.

In the present study, we determined the degree of the stability and duration of extensive ice cover. Two ice cover properties, namely its extent and duration, were integrated into a complex characteristic. Using this characteristic, we identified a regime shift in the ice season characteristics.

The average ice concentrations over the Baltic Sea in the periods before and after the shift were compared. These values were $18 \%$ before and $10 \%$ after the shift.

The study of the ice season characteristics, namely season characteristic difference, peak duration value (number of days with the ice extent of $\geq 80 \%$ of the season maximum), and the skewness of air temperature distribution, indicated an ice climate regime shift in 2006-2007.
The average ice concentration, number of ice days, sum of weighted ice days, date of the Emax, sum of negative degree days, and air temperature spectrum differed before and after the shift.

After 2007, water transparency decreased considerably earlier than before 2007, reaching a value of $0.4 \mathrm{~m}-1$ [11]. This change coincides with the regime shift identified in our study. The water may have lost its transparency earlier due to the shorter duration of the extensive ice cover and lower ice concentration.

The air temperature distribution changed in the southern Baltic region (the skewness, on average, was 0.39 before and 0.8 after the shift); however, the ice season characteristics indicated that the regime shift was mainly because of the northern Baltic region. The air temperature is more variable in the southern Baltic region than in the northern region. I supposed that the Baltic Sea climatic change was mainly caused by processes in its southern region. The study demonstrated that the temperature variability in the southern region does not directly result in ice climate change because this sea area lacks ice. However, the higher temperature in the southern region after the shift caused open water to prevail over the ice there. The warmer water can flow from south to north, contributing to ice melting in the northern region of the sea.

Various ice property observation technologies (satellite, radars, in situ observations by ice-breakers, and stations) have been used to obtain the data used in the study. Satellite observation technology has been rapidly progressing towards higher resolution; consequently, the data for recent winters are considerably more reliable than those for the initial part of the period.

The results of this research could be supplemented by investigating whether the shift ice season characteristics are associated with changes in water circulation patterns and largescale climatic processes and by evaluating the nature of the association.

The statistical features of the ice concentration and the number of ice days differ before and after the shift by at least $40 \%$ (the values of these characteristics decreased after the shift). The date of the season's Emax event shifted 1 month earlier.

The future studies and precautions.

Ice conditions for maritime traffic in the Baltic Sea in past/ present and future climates were investigated [21-22]. The change in sea ice and thermal regime can directly control the level of growth and reproduction of the species.

As the ice melting period has received little attention among ecology modelers, it deserves to be studied

Safety maritime winter navigation in the Baltic Sea should get more attention and risk-management [23]

This study confirms previous knowledge, ice conditions will become milder. Ice coverage decreases and ice seasons shorten. Therefore more ports can be operated without maritime traffic restrictions for a longer part of the year. But the study also shows that extreme cold temperatures occur for short periods during winter season. In the short term, moderate or severe ice conditions occur. In this conditions, ships gets stuck in ice [24], for example, the tanker was stuck in ice for 60 hours in spring 2010 in nort of Gulf of Finland and 15 accidents took place in ice conditions in 2013, [25-26].

- Safety of offshore and shore buildings.

When planning wind farms should be considered by severe ice conditions occurred short term and that there is a risk of ridge ice 
formation. Planning of submarine cables there must to take into account the dangers of ridge ice in the shore area.

\section{REFERENCES / Literatura}

[1] Tarand, A. and Nordli, P.: The Tallinn temperature series reconstructed back half a millennium by use of proxy data, in The Iceberg in the Mist: Northern Research in pursuit of a Little Ice Age. Springer, 2001; pp. 189-199. https:// doi.org/10.1007/978-94-017-3352-6_9

[2] Schmelzer, N. and Holfort, J.: Ice winter severity in the Western Baltic Sea in the period of 1301-1500: comparison to other relevant data, Int. J. Climatol. 31, 1094-1098 (2011). https://doi.org/10.1002/joc.2337

[3] BACC II Author Team, Second assessment of climate change for the Baltic Sea Basin (Regional Climate Series), (SpringerOpen, Cham, 2015). https:// doi.org/10.1007/978-3-319-16006-1

[4] Schmelzer, N.; Seinä, J.; Lundqvist, E. and Sztobryn, M.: Ice, in State and Evolution of the Baltic Sea, 1952-2005: A Detailed 50-Year Survey of Meteorology and Climate, Physics, Chemistry, Biology, and Marine Environment, Ed. by R. Feistel, G. Nausch, and N. Wasmundpp 2008; pp. 199-240. https://doi.org/10.1002/9780470283134.ch8

[5] Vainio, J.: The Sea Ice season 2010-2012. HELCOM Baltic Sea Environment Fact Sheets 2011. http://www.helcom.fi/Documents/Balticsea_trends/ Environment_fact_sheets/BSEF_HELCOM_-_The_ice_season_2010-2011. pdf. (Accessed March 18, 2017)

[6] Vihma, T. and Haapala, J.: Geophysics of sea ice in the Baltic Sea: a review, Prog. Oceanogr. 80, 2009; 129-148. https://doi.org/10.1016/j. pocean.2009.06.001

[7] Omstedt, A. and Chen, D.: Influence of atmospheric circulation on the maximum ice extent in the Baltic Sea, J. Geophys. Res. Oceans. 2001, 106(C3), 4493-4500. https://doi.org/10.1029/1999jc000173

[8] Pawlak, J. F. (Ed.): Climate Change in the Baltic Sea Area: HELCOM Thematic Assessment in 2013 (Helsinki Commission, Baltic Marine Environment Protection Commission, 2013).

[9] Jevrejeva, S.; Drabkin, V.; Kostjukov, J.; Lebedev, A.; Leppäranta, M.; Mironov, U. and Sztobryn, M.: Baltic Sea ice seasons in the twentieth century, Clim. Res. 2004; 25(3), 217-227. https://doi.org/10.3354/cr025217

[10] Jaagus, J.; Briede, A.; Rimkus, E. and Remm, K. Variability and trends in daily minimum and maximum temperatures and in the diurnal temperature range in Lithuania, Latvia and Estonia in 1951-2010, Theor. Appl. Climatol. 2014; 118, 57-68. https://doi.org/10.1007/s00704-013-1041-7

[11] Kahru, M.; Elmgren, R. and Savchuk, O. P.: Changing seasonality of the Baltic Sea, Biogeosci. Discuss. 2016; 13(4), 1009-1018. https://doi.org/10.5194/ bg-13-1009-2016
[12] Rodionov, S. and Overland, E.: Application of a sequential regime shift detection method to the Bering Sea ecosystem, ICES J. Mar. Sci. 2005; 62(3) 328-332. https://doi.org/10.1016/j.icesjms.2005.01.013

[13] Stips, A. and Lilover, M.: How to detect regime shifts in the Baltic Sea area and their causes?, in Abstract book Baltic Sea Science Congress 2013: Baltic Sea Science Congress 2013 New Horizons for Baltic Sea Science; 26-30 August 2013 (Klaipeda, Lithuania, 2013), p. 114. https://doi.org/10.1109/ baltic.2012.6249164

[14] Keevallik, S.: Shifts in meteorological regime of late winter and early spring in Estonia during recent decades," Theor. Appl. Climatol. 105, 209-215 (2011). https://doi.org/10.1007/s00704-010-0356-x

[15] Hagen, E. and Feistel, R.: Climatic turning points and regime shifts in the Baltic Sea region: the Baltic winter index (WIBIX) 1659-2002, Boreal Environ. Res. 2005; 10(3), 211-224.

[16] Pärn, O.; Rjazin, J. and Uiboupin, R.: The ice seasons severity by the sum of ice extent on the Baltic Sea during 1982-2015. Mult. Drivers Earth Syst. Chang. Baltic Sea Reg. 2016; 151.

[17] Rjazin, J.; Alari, V. and Pärn, O. “Classifying the ice seasons 1982-2016 using the weighted ice days number as a new winter severity characteristic" Eureka 5, 49-56 (2017). https://doi.org/10.21303/2461-4262.2017.00364

[18] Rodionov, S.: "A sequential algorithm for testing climate regime shifts," Geophys. Res. Lett. 2004; 31, L09204. https://doi.org/10.1029/2004gl019448

[19] Ruskule, A.; Kuris, M.; Leiputè, G.; Vetemaa, M. \& Zableckis, S.: See the Baltic Sea unique asset we share, Baltic environmental forams (2009).

[20] Rjazin, J. and Pärn, O. "Determining the ice seasons severity during 19822015 using the ice extents sum as a new characteristic," in EGU General Assembly Conference Abstracts, Vol. 18, p. 3020 (2016). https://doi. org/10.21303/2461-4262.2017.00364

[21] Höglund, A.; Pemberton, P.; Hordoir, R.; Schimanke, S.: Ice conditions for maritime traffic in the Baltic Sea in future climate. Boreal Environ. Res. 2017.

[22] Pärn, O.; Lessin, G.; Stips, A.: Efects of sea ice on phytoplankton spring bloom in the central and southern Baltic Sea: a modelling case study. Oceanologia 2020, manuscript accepted 09.03.2020

[23] HELCOM Baltic Sea Clean Shipping Guide, 2017.

[24] Rjazin, J.; Pärn, O. A.: Case study of the wind impact on ship ice-sticking TransNav: International Journal on Marine Navigation and Safety of Sea Transportation. 2016. https://doi.org/10.12716/1001.10.04.06

[25] HELCOM, Annual report on shipping accidents in the Baltic Sea in 2013. 2014.

[26] Banda, O. V.; Goerlandt, F.; Montewka, J.; Kujala, P.: Winter navigation at the Baltic Sea: an analysis of accidents occurred during winters 2002-2003 \& 2009-2013. Safety and Reliability. Methodology and Applications, CRC Press, The Netherlands. 2015. https://doi.org/10.1201/b17399-14 